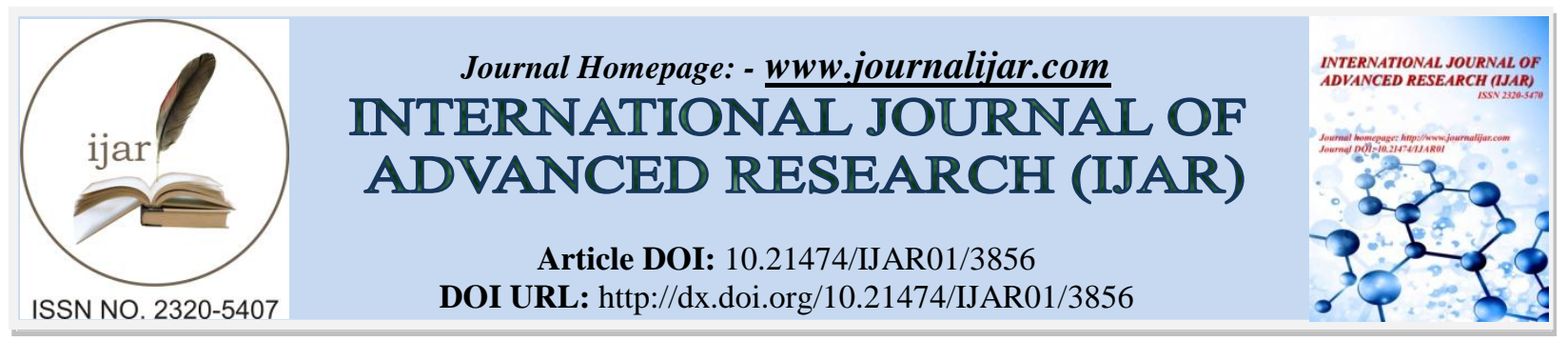

RESEARCH ARTICLE

\title{
ESTIMATION THE ABILITY OF WATER, EXTRACTS OF BARLEY SEEDS AND DATE PALM SEEDS, ON KIDNEY STONE DECOMPOSITION IN VITRO.
}

\begin{abstract}
Abdulwahid Shamkhi Jabir.
Al-Nahrain University, College of biotechnology - Bagdad Iraq.
\end{abstract}

\section{Manuscript Info}

Manuscript History

Received: 05 February 2017

Final Accepted: 06 March 2017

Published: April 2017

\begin{abstract}
Kidney stones seen to be an important health problems over the world. There are many reasons can be lead to these problems. Locally, barley seeds and date palm seed extracts used as decompose of stones. This work has been carried out in several places, but mainly in Biochemistry laboratory of Dept. of Biotechnology in Al-Nahrain University. The stones were taken from Al-Yarmook Teaching Hospital by surgery for patients suffering from renal stones, with an age range (34-49) years old mostly male. The stones were treated separately with two different plant extracts.. Date palm and barley seeds which were used in this work obtained from local market. Barley seed extract and Date palm seed gave different significance decomposes with the different types of stones and different period of soaking time. Barley seed extract gives (17.42 $\mathrm{mg} / \mathrm{ld}$ calcium and $16.39 \mathrm{mg} / \mathrm{ld}$ of uric acid). Ate palm seed gives $(6.74 \mathrm{mg} / \mathrm{dl}$ calcium and 14.09 of uric acid).
\end{abstract}

Copy Right, IJAR, 2017,. All rights reserved.

\section{Introduction:-}

The kidney is an important organ of the human. It has many functions such as remove waste products from the body, blood pressure regulation, keep body's chemicals in balance, and maintain the body's water balance (Chandhoke, P S ,2007) There are many different renal problems that may occur. Kidney stones represent the most commonly important problems over the world. The type of stones may also form in the ureter or in the bladder (Parmar, MS,2004), (Moe OW., 2006). The stone can make many uncomfortable problems for the patients suffering from kidney stones. A lot of studies have been done in many countries to control this problem ( Smith et al 2010). In different area over the world urinary tract stones tend to be more common in children than adults [5]. Kidney stones occur when when a different types of salts are aggregate and precipitate and form solid materials. Stones can vary in size ( Knight KF,2000).

Stones can also form if substances are at normal levels. The substances form crystals, which become anchored in the kidney and gradually increase in size, forming a kidney stone. Normally the stone will move through the urinary tract and pass out in the urine. But, when it is stuck and blocks the urine flow, then it causes pain. Large stones do not always pass through and may require a procedure or surgery to remove them. Some of the habits that can increase the risk of stone formation (KAABI H. 2009). There are many habits that can cause stone problems depend upon the types of food taken. 
Not all kidney stones cause discomfort, but pain is normally the first sign. Pain can range from a mild and barely noticeable ache to discomfort that is so intense it requires hospital treatment. Typically, the pain gets worse and better, but does not go away completely. Waves of severe pain, known as renal colic, usually last from twenty to sixty minutes. Pain can occur in the flank (the side, between the ribs and the hip) or the lower abdomen (Preminger GM, and Curhan GC. 2009). Patients with kidney stones will have blood in the urine (hematuria). The urine may be pink or reddish but will show the presence of blood when tested with urine dipstick. Other symptoms include the passing of gravel or small stones in the urine, nausea or vomiting, pain during urination and an urgent need to urinate (Rose BD., 2009). Some natural product such as date Palm seeds contain some chemical compound work as antioxidant and many other materials which help to prevent kidney and liver also it has some compound acting as anti free radical (Ahmed AF1, et al, 2015), (Takaeidi MR1, et al, 2014), (Ambigaipalan P1, and Shahidi F 2015). Some other studies indicate that date Palm seeds contain an active compounds could prevent DNA and work as antiviral activity (Abdelaziz DH, and Ali SA, 2014), (Jassim SA, and Naji MA, 2010). The barley seed extract also containing an active compound can be acting as an antioxidant ( Qing Liu, and Huiyuan Yao (2007), 16), (Yang Qingming, et al, 2010).

\section{Material and Methods:-}

\section{Material:-}

The equipments and apparatus had been used in this study; Oven, Sensitive Balance, centrifuge, spectrophotometer, Shaker water bath.

\section{Chemicals and Kits:-}

These Kits were used; Uricase kit, BIOLABO/France and CPC kit, BIOLABO/France.

\section{Plant extract:-}

Preparation of Date palm seed extract:-

Date palm seeds washed well and then were dried and milled and prepare its own plant extract by but $50 \mathrm{~g}$ of date palm seeds, flour in $250 \mathrm{ml}$ of distilled water and then was placed in a shaker water bath for 6 hours, after that the extract filtered by filter paper and kidney stones placed in it.

\section{Preparation of Barley seed extract:-}

Barley extract was prepared in the same manner previously mentioned. After grinding the barley seed, $50 \mathrm{~g}$ of barley seed soaked in $250 \mathrm{ml}$ of distilled water and the solution was placed in a shaker water bath for 6 hours, then the extract filtered by filter paper and kidney stones placed in it

\section{Method of treatment:- \\ Measurement of Uric Acid concentration (Uricase Method):-}

Uric acid concentration was measured by using a kit which obtained commercially from (BIOLABO/France). Kit depends on Uricase acts on uric acid to produce alienation, carbon dioxide and hydrogen peroxide. Hydrogen peroxide in the presence of peroxide reacts with a chromogen to yield quinoneimine a red colored complex. The absorbance measured at $700 \mathrm{~nm}$ is proportional to the amount of uric acid in the specimen. The procedure was as follows: $1.8 \mathrm{ml}$ of reagent was put in the tube and then $0.2 \mathrm{ml}$ of sample was added and mixing. The mixture was kept for 10 minutes at $37^{\circ} \mathrm{C}$. After that the observance was measured at $700 \mathrm{~nm}$. The results were calculated according to this formula: uric acid concentration $=$ Test $/$ Stander $*$ factor. The value of the factor given by the supplier in this case was (6).

\section{Measurement of Calcium Concentration (CPC Method):-}

Calcium concentration was measured by using a kit which obtained commercially from (BIOLABO/France). Kit depends on a CPC (O-Cresol Phtalein Complexone) in alkaline solution, it reacts with calcium to form a dark red colored. The complex, which, absorbed at $570 \mathrm{~nm}$. It is proportional to the amount of calcium in the specimen. In this procedure, two reagents were used, $0.5 \mathrm{ml}$ of reagent, one and $0.5 \mathrm{ml}$ of reagent two mixed and then $20 \mathrm{ul}$ of stander were added and the absorbance measure at $570 \mathrm{~nm}$. The same thing was repeated, but we add $20 \mathrm{ul}$ of the sample instead of stander and kept at $37^{\circ} \mathrm{C}$ for 10 minutes and then the absorbance was measured at $520 \mathrm{~nm}$. The result, then calculated according to the formula: calcium concentration $=$ Test $/$ Standard $*$ factor. The factor in this case was (8). 


\section{Statistic analysis:-}

The Genstas program was employed to do the analysis for the date in this study by using split plot design.

\section{Results and Discussion:-}

The experiment was designed to measure the effect of two of plant extracts on the dissociation of uric acid and calcium, which give an indication about the effect of these extracts on the different type of kidney stones. Date palm seed, water extract (DPS) and Barley seed, water extract (BRS). Table 1 showed the overlapping of three factors affecting the decomposition of the different types of kidney stones as uric acid. These factors are type of stones, time of soaking and types of plant extract used. From this table found that there are a significant overlapping between oxalate stone, time of soaking(overnight) and type barley extract to give a high production of uric acid $(16.39 \mathrm{mg} / \mathrm{dl})$. But the soaking same stones with same extract for five hours just give (7.52 mg/ld of uric acid). From same table it has been found that the effect of the date palm extract comes in the second stage of significant given (14.09 mg/ld uric acid) for overnight to the same type of stone. On the other hand it also was significant with the five hours time $(13.58 \mathrm{mg} / \mathrm{ld}$ uric acid). The other part of table 1 show overlapping with calcium stone. In that part it has been found the date palm extract with soaking time overnight gave high value of significant (14.09 mg/dl uric acid) and the second significant value for the same type of extract (date palm seed) with five hours of soaking. In general it is seen to be that there is a relation between the type of stones and the type of extract and time. Barley seed extract more active with oxalate stone than calcium stone, but need time to work. The date palm extract more active with calcium stone and fast.

Table 1:- The effect of the types of stones, time of soaking and the types of plant extract on the concentration of uric acid.

\begin{tabular}{|c|c|c|c|c|c|c|}
\hline \multirow[t]{2}{*}{ Types of stones } & \multirow[t]{2}{*}{ Time of soaking } & \multicolumn{2}{|c|}{$\begin{array}{c}\text { Mean of types of } \\
\text { plant extract }\end{array}$} & \multirow[t]{2}{*}{$\begin{array}{l}\text { Mean soaking } \\
\text { types X time }\end{array}$} & \multirow[t]{2}{*}{$\begin{array}{l}\text { Means soaking } \\
\text { types }\end{array}$} & \multirow[t]{2}{*}{ Mean time } \\
\hline & & DPS & BRS & & & \\
\hline \multirow[t]{3}{*}{ Oxalate stones } & 5 hours & 13.58 & 7.52 & 10.55 & & \\
\hline & Overnight & 14.09 & 16.39 & 15.24 & & \\
\hline & $\begin{array}{l}\text { Mean soaking } \\
\text { types X Extract }\end{array}$ & 13.84 & 11.96 & & 12.90 & \\
\hline \multirow[t]{3}{*}{ Calcium stones } & 5 hours & 13.45 & 10.58 & 12.01 & & \\
\hline & Overnight & 13.98 & 10.49 & 12.23 & & \\
\hline & $\begin{array}{l}\text { Mean soaking } \\
\text { types X Extract }\end{array}$ & 13.84 & 10.54 & & 12.12 & \\
\hline \multirow{2}{*}{$\begin{array}{l}\text { Mean time X } \\
\text { Extract }\end{array}$} & 5 hours & 13.51 & 9.05 & & & 11.287 \\
\hline & Overnight & 14.03 & 13.44 & & & 13.742 \\
\hline \multicolumn{2}{|l|}{ Mean of Extract } & 13.77 & 11.25 & & & \\
\hline $\begin{array}{l}\text { L.S.D } \\
0.05\end{array}$ & \multicolumn{6}{|c|}{$\begin{array}{l}\text { L.S.D. Soaking types }=0.35 \text {, L.S.D. time }=0.35 \text {, L.S.D. Extract }=0.35 \\
\text { L.S.D. Soaking types X time } 0.50, \text { L. S. D. Soaking types X Extract }=0.50 \\
\text { L.S.D. Time X Exract }=0.50 \text { L.S.D. Soaking X Time X Extract }=0.713\end{array}$} \\
\hline
\end{tabular}

Table 2 shows the overlapping of the same plant extract and same period of time in the production of calcium in $\mathrm{mg} / \mathrm{ld}$. From that table it had been seen that the more significant is the barley extract after overnight soaking (17.42 $\mathrm{mg} / \mathrm{ld}$ calcium) and the second value also for barley seed extract gave (14.62 mg/ld calcium) after five hours soaking. The date palm seed gave the least value for the both periods of time five hours and overnight (6.51 and 6.74 $\mathrm{mg} / \mathrm{ld}$ calcium respectively).

The data listed in table three represent the difference in weight of the both kinds of stone before and after soaking in the plant seed extract as general indication. It cannot be gotten as a stander because the moisture cannot be controlled as same before and after s soaking. 
Table 2:- The effect of the types of stones, time of soaking and the types of plant extract on the concentration of calcium

\begin{tabular}{|c|c|c|c|c|c|c|}
\hline \multirow[t]{2}{*}{$\begin{array}{l}\text { Types of } \\
\text { stones }\end{array}$} & \multirow[t]{2}{*}{ Time of soaking } & \multicolumn{2}{|c|}{$\begin{array}{l}\text { Mean of types } \\
\text { of plant extract }\end{array}$} & \multirow[t]{2}{*}{$\begin{array}{l}\text { Mean soaking } \\
\text { types X time }\end{array}$} & \multirow[t]{2}{*}{$\begin{array}{l}\text { Means } \\
\text { soaking types }\end{array}$} & \multirow[t]{2}{*}{ Mean time } \\
\hline & & DPS & BRS & & & \\
\hline \multirow{3}{*}{$\begin{array}{l}\text { Oxalate } \\
\text { stones }\end{array}$} & 5 hours & 6.51 & 14.62 & 10.57 & \multirow[t]{2}{*}{11.32} & \\
\hline & Overnight & 6.74 & 17.42 & 12.08 & & \\
\hline & $\begin{array}{l}\text { Mean soaking types } \mathrm{X} \\
\text { Extract }\end{array}$ & 6.63 & 16.02 & & & \\
\hline \multirow{3}{*}{$\begin{array}{l}\text { Calcium } \\
\text { stones }\end{array}$} & 5 hours & 5.93 & 17.72 & 11.58 & \multirow[t]{2}{*}{11.41} & \\
\hline & Overnight & 6.28 & 16.22 & 11.25 & & \\
\hline & $\begin{array}{l}\text { Mean soaking types } \mathrm{X} \\
\text { Extract }\end{array}$ & 6.10 & 16.97 & & & \\
\hline \multirow{2}{*}{$\begin{array}{l}\text { Mean time X } \\
\text { Extract } \\
\end{array}$} & 5 hours & 6.22 & 15.92 & & & 11.07 \\
\hline & Overnight & 6.51 & 16.82 & & & 11.66 \\
\hline \multicolumn{2}{|c|}{ Mean of Extract } & 6.37 & 16.37 & & & \\
\hline \multicolumn{2}{|l|}{$\begin{array}{l}\text { L.S.D } \\
0.05\end{array}$} & $\begin{array}{l}\text { types = } \\
\text { types X } \\
\text { Exract }=\end{array}$ & $\begin{array}{l}0.34, \mathrm{~L} . \mathrm{S} \\
\text { ime } 0.48 \\
\text { o.48, L. }\end{array}$ & $\begin{array}{l}\text { D. time }=0.34, \mathrm{~L} \text {. } \\
\text { L. S. D. Soaking } \\
\text { D. Soaking X T }\end{array}$ & $\begin{array}{l}\text { D. Extract = } \\
\text { types X Extra } \\
\text { ne X Extract }\end{array}$ & $\begin{array}{l}0.48 \\
8 \\
\end{array}$ \\
\hline
\end{tabular}

Table 3:- The direct effect of plant extract on the weight of kidney stone

\begin{tabular}{|c|c|l|c|c|}
\hline $\begin{array}{c}\text { Type of } \\
\text { stones }\end{array}$ & Time of soaking & Type of plant extract & $\begin{array}{c}\text { Weight before } \\
\text { soaking }\end{array}$ & Weight after soaking \\
\hline \multirow{2}{*}{$\begin{array}{c}\text { Oxalate } \\
\text { stones }\end{array}$} & 5 hours & Date palm seed extract & $5.11 \mathrm{~g}$ & $5.05 \mathrm{~g}$ \\
\cline { 2 - 5 } & & Barley seed extract & $5.09 \mathrm{~g}$ & $5.08 \mathrm{~g}$ \\
\cline { 2 - 5 } & Overnight & Barley seed extract & $4.47 \mathrm{~g}$ & $4.46 \mathrm{~g}$ \\
\hline \multirow{2}{*}{$\begin{array}{c}\text { Calcium } \\
\text { stone }\end{array}$} & 5 hours & Date palm seed extract & $8.19 \mathrm{~g}$ & $8.06 \mathrm{~g}$ \\
\cline { 2 - 5 } & & Barley seed extract & $8.19 \mathrm{~g}$ & $8.11 \mathrm{~g}$ \\
\cline { 2 - 5 } & Overnight & Barley seed extract & $5.73 \mathrm{~g}$ & $5.70 \mathrm{~g}$ \\
\hline
\end{tabular}

\section{Conclusions and Recommendations:-}

\section{Conclusions:-}

It has been found that plant extracts give an indication that can be used to treat kidney stones. In general Barley seed extract show more active effect on the both types of stones. This study can be continued with a cooperation with hospital to treat patients and see the direct effect and may we need to use a mixture of the extract.

\section{Recommendations:-}

This study can be continued with a cooperation with hospital treated volunteers, patient and see the direct effect.

\section{References:-}

1. Chandhoke, P S . Evaluation of the recurrent stone former (2007). Urol Clin North Am 2007; 34 (3) 315

2. Parmar, MS (2004). "Kidney stones". British Medical Journal 328 (7453): 1420-4.

3. Moe OW, (2006) Kidney stones: pathophysiology and medical management . The Lancet 2006; 367 (9507): $333-44$

4. Smith J, Mattoo TK, Stapleton FB.(2010) Patient information: Kidney Stones in children. Samoa Medical Journal, volume 2, 2010.

5. Kidney Health Australia.(2010). Fast facts on Chronic Kidney Disease (CKD). Patient information resources. Samoa Medical Journal, volume 2, 2010.

6. Knight KF. (2000) Kidney Stones. Christchurch: Kidney Health New Zealand. Samoa Medical Journal, volume 2, 2010.

7. KAABI H. (2009). National Project of Date Palm, Phoenix, dacylifera. UAE-University.

8. Preminger GM, Curhan GC.(2009) Patient information: Kidney Stones in adults. Samoa Medical Journal 2010.

9. Rose BD.(2009). Patient information: Blood in the urine (hematuria) in adults. Samoa Medical Journal 2010. 
10. Ahmed AF1, Al-Qahtani JH, Al-Yousef HM, Al-Said MS, Ashour AE, Al-Sohaibani M, Rafatullah S (2015). Proanthocyanidin-rich date seed extract protects against chemically induced hepatorenal toxicity. J Med Food. 2015 Mar;18(3):280-9.

11. Takaeidi MR1, Jahangiri A2, Khodayar MJ3, Siahpoosh A4, Yaghooti H5, Rezaei S6, Salecheh M1, Mansourzadeh Z (2014). The Effect of Date Seed (Phoenix dactylifera) Extract on Paraoxonase and Arylesterase Activities in Hypercholesterolemic Rats Jundishapur J Nat Pharm Prod. 2014 Feb;9(1):30-4. Epub 2014 Feb 15.

12. Ambigaipalan P1, Shahidi F (2015). Antioxidant potential of date (Phoenix dactylifera L.) seed protein hydrolysates and carnosine in food and biological systems.Ambigaipalan P1, Shahidi F. J Agric Food Chem. 2015 Jan 28;63(3):864-71.

13. Abdelaziz DH, Ali SA( 2014). The protective effect of Phoenix dactylifera L. seeds against CCl4-induced hepatotoxicity in rats. J Ethnopharmacol. 2014 Aug 8;155(1):736-43.

14. Jassim SA, Naji MA (2010). In vitro Evaluation of the Antiviral Activity of an Extract of Date Palm (Phoenix dactylifera L.) Pits on a Pseudomonas Phage. Evid Based Complement Alternat Med. 2010 Mar;7(1):57-62.

15. Qing Liu, Huiyuan Yao (2007). Antioxidant activities of barley seeds extracts. Food Chemistry, Volume 102, Issue 3, 2007, Pages 732-737.

16. Yang Qingming, Pan Xianhui, Kong Weibao, Yang Hong, Su Yidan, Zhang Li, Zhang Yanan, Yang Yuling, Ding Lan, Liu Guoan (2010). Antioxidant activities of malt extract from barley (Hordeum vulgare L.) toward various oxidative stress in vitro and in viv. Food Chemistry, Volume 118, Issue 1, 1 January 2010, Pages 84-89 